\title{
Transport of crab larval patches in the coastal ocean
}

\author{
Cecily C. Natunewicz ${ }^{1, *}$, Charles E. Epifanio ${ }^{2}$, Richard W. Garvine ${ }^{3}$ \\ ${ }^{1}$ NOAA/ NMFS, 101 Pivers Island Rd, Beaufort, North Carolina 28516, USA \\ ${ }^{2}$ University of Delaware, Graduate College of Marine Studies, 700 Pilottown Rd, Lewes, Delaware 19958, USA \\ ${ }^{3}$ University of Delaware, Graduate College of Marine Studies, Robinson Hall, Newark, Delaware 19706, USA
}

\begin{abstract}
We assessed the role of wind and buoyancy forcing on the transport of newly hatched blue crab larvae Callinectes sapidus near the mouth of Delaware Bay, USA. Eight patches of larvae were tagged with satellite-tracked drifters and followed for periods of 1 to $11 \mathrm{~d}$. We conducted daily plankton tows within a $3.2 \mathrm{~km}^{2}$ area circumscribing each drifter. This allowed us to verify that each drifter remained within a patch. Trajectories of the patches were assessed in relation to physical data (salinity, temperature, winds, and river discharge) and compared to trajectories predicted by a 2-dimensional mathematical model. Analysis of CTD data indicated that 3 patches were initially tagged in the coastal plume emanating from Delaware Bay, while 5 patches were initially tagged in shelf water adjacent to the plume. Patches occurring in plume waters traveled farther down-shelf (southward) than those in adjacent shelf waters. Winds modified this along-shelf transport. Specifically, upwelling-favorable (northward) winds mixed larvae offshore and out of the coastal plume. Downwelling-favorable (southward) winds drove patches of larvae across the continental shelf and toward the coast. Trajectories were simulated well by the mathematical model. As river discharge diminished in the late summer, the effect of winds (relative to buoyancy forcing) on larval transport increased. This shift in the dominant forcing mechanism was demonstrated both by the trajectories of the tagged larval patches and by predictions from the mathematical model.
\end{abstract}

KEY WORDS: Delaware Bay $\cdot$ Callinectes sapidus $\cdot$ Drifters $\cdot$ Zoeae $\cdot$ Transport $\cdot$ Patches Resale or republication not permitted without written consent of the publisher

\section{INTRODUCTION}

A common goal of coastal research is to understand the processes by which materials are exchanged between estuaries and the continental shelf. The fates of particles, chemicals, and organisms released in estuaries and exported to shelf waters have important implications for the health of coastal environments and for the population dynamics of their inhabitants. In this study we examined the transport of larvae of an estuarine-spawned species, the blue crab Callinectes sapidus, from hatching grounds in the mouth of Delaware Bay to the adjacent coastal ocean. Specifi-

*E-mail: cecily.natunewicz@noaa.gov cally, we elucidated the roles of wind and buoyancy forcing on the trajectories of larvae released near the mouth of Delaware Bay.

Previous attempts to determine trajectories of larval transport have involved a combination of biological sampling and drifter deployments. In one approach, physical and biological sampling are de-coupled in space or time, and conclusions are drawn from separate analysis of the 2 data sets (e.g., Pepin \& Helbig 1997, Brown et al. 1999). An alternative approach employs integrated sampling programs wherein physical and biological data are collected and analyzed simultaneously. The majority of these integrated studies have concentrated on fish larvae and have used a combination of radar and radio-direction techniques to track surface drifters that had been deployed in nomi- 
nal patches of larvae (e.g., Fortier \& Leggett 1985, Zenitani et al. 1996). These investigations involve continuous tracking of drifters, combined with frequent plankton sampling in the area around the drifter. Similar work has analyzed trajectories of crab larvae within the coastal plume of Chesapeake Bay (Roman \& Boicourt 1999).

The above investigations have met with varying degrees of success and, in addition to determining trajectories, have allowed field estimates of parameters such as mortality and growth rates (Fortier \& Leggett 1985, Zenitani et al. 1996). However, none of the studies has ascertained that drifters were deployed in an actual patch of larvae and none has tracked even a nominal patch for more than a few days. Our study differs pointedly in these 2 respects, as it involved tagging confirmed patches of blue crab larvae with satellite-tracked drifters and following the trajectories of the patches for periods up to $11 \mathrm{~d}$.

In the Middle Atlantic region of North America, blue crab larvae are released in summer and are exported from the mouths of estuaries to the coastal ocean. The larvae develop through 7 zoeal stages in surface waters of the inner continental shelf. This is followed by a single post-larval stage that eventually settles and undergoes metamorphosis in nursery habitat within the estuary. Duration of larval development ranges from 3 to 6 wk (Epifanio 1995).

Details of larval transport in the Middle Atlantic region have been described in recent conceptual and

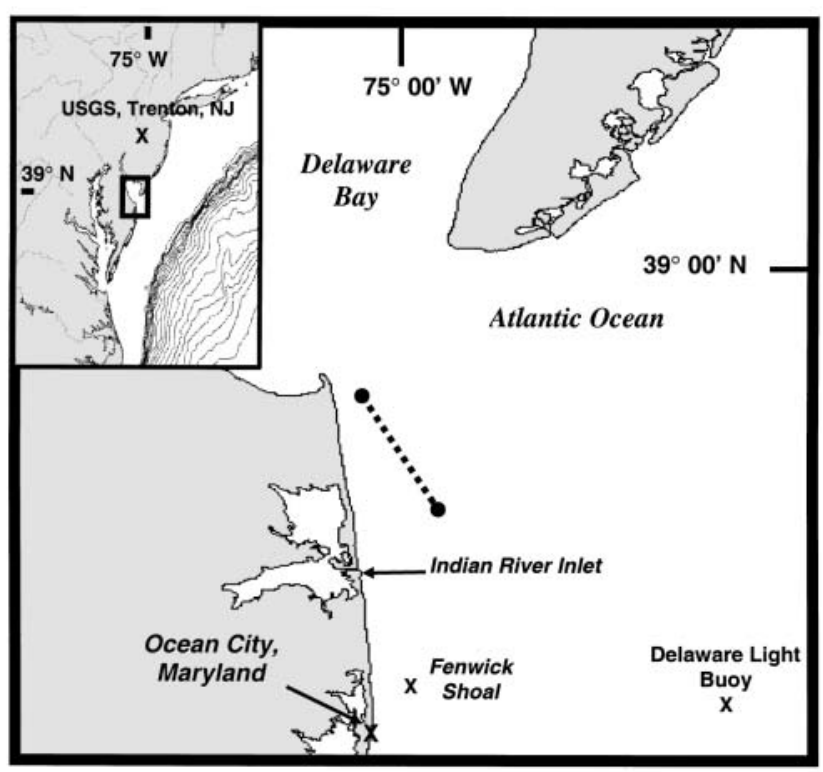

Fig. 1. Study site. Delaware Bay, USA. Representative transect (dashed line) sampled in the summer of 1999. Inset: Middle Atlantic Bight, USA. Discharge data were collected at the USGS station in Trenton, NJ mathematical models (Epifanio 1995, Garvine et al. 1997). These models stipulate initial transport of larvae southward along the inner continental shelf along with the buoyant estuarine plume. Retention on the continental shelf near the estuary is provided by a winddriven band of water flowing northward along the mid-shelf. Across-shelf transport to estuarine settlement sites is accomplished by coastal Ekman circulation associated with discrete southward wind events (Jones \& Epifanio 1995).

A key assumption of the conceptual model is that larvae are transported in distinct patches. In the summers of 1997 and 1998, we determined the spatial scale of patches of blue crab larvae near the mouth of Delaware Bay (Natunewicz \& Epifanio 2001). Typical patches had larval concentrations of $10^{2}$ to $10^{3}$ larvae $\mathrm{m}^{-3}$ compared to concentrations $<10 \mathrm{~m}^{-3}$ in water outside a patch. Mean dimensions of the patches were on the order of $2 \mathrm{~km}$ in both the along-shelf and acrossshelf directions.

In the present paper we describe an investigation that used tracking techniques to test the conceptual model for transport of patches in the Middle Atlantic Bight. Specifically, we determined the extent to which blue crab larvae are initially transported from the mouth of Delaware Bay in the coastal plume. Additionally we assessed the effect of northward winds in driving larvae out of the plume region and into coastal waters, as well as the role of southward winds in returning larvae to local estuaries. Finally we compared the observed trajectories to trajectories generated by a mathematical model that was run with actual wind and river-flow data from the observation periods.

\section{MATERIALS AND METHODS}

Study area. Work was conducted in the southern Middle Atlantic Bight at the mouth of Delaware Bay (Fig. 1). Subtidal flow in the area is influenced by a buoyant plume that emanates from the bay. The plume flows southward along the coast and counter to the prevailing winds that are typical of summer in the region. These winds result in an upwelling circulation along the coast and also produce northward surface flow just offshore of the plume (Garvine et al. 1997). Early autumn is characterized by an increased frequency of southward wind events. These events drive downwelling circulation, which causes an increase in sea level along the coast, followed by barotropic flow into the bay. Wind-velocity data for the region are collected routinely at the Delaware Bay Buoy (National Data Buoy Center \#44009), and discharge data for the Delaware River are gathered at the United States Geological Survey station in Trenton, New Jersey (Fig. 1). 
Identifying and tracking larval patches. The blue crab life cycle provides an ideal system in which to examine larval transport by means of tagging and tracking patches of larvae in real time. Recent work has shown that newly hatched Callinectes sapidus larvae remain in cohesive patches on a scale of days to weeks (Natunewicz \& Epifanio 2001). Additionally, the restricted distribution of blue crab zoeae in the upper $2 \mathrm{~m}$ of the water column (Epifanio 1995) permits the use of satellite-communicating surface drifters and 2-dimensional mathematical models.

Patches were identified by continuous plankton sampling along a transect on the inner continental shelf adjacent to the mouth of Delaware Bay (Fig. 1). During each drifter deployment, a series of 12 to 24 continuous plankton tows (Table 1, net $=0.5 \mathrm{~m}$ diameter, $253 \mu \mathrm{m}$ mesh; tow length $=300 \mathrm{~m}$; depth $=$ surface) was conducted, wherein the release of one net coincided with the recovery of another (Natunewicz \& Epifanio 2001). Sampling was performed near high slack water to minimize effects of water movement relative to the sampling boat. The volume of water filtered for each tow was calculated from flowmeter readings, and the abundance of larvae $\left(\mathrm{m}^{-3}\right)$ in each sample was determined on the day of collection by standard microscopic analysis. The linear dimension of the patches was determined by autocorrelation of larval concentrations along each transect (Richerson et al. 1977).
We deployed drifters (Horizon Marine, Inc.) on 8 separate days during the summer of 1999 (Table 1). Each drifter had a cylindrical buoy that extended about $30 \mathrm{~cm}$ above the surface and contained the transmitter. The buoy was attached to a drogue centered at $2 \mathrm{~m}$ depth.

During each deployment we released a maximum of 4 individual drifters at $1800 \mathrm{~m}$ intervals (i.e., every 6th plankton tow) along the transect. Because we could not know the location of patches a priori, releasing a drifter at each of several positions along the transect increased the probability of tagging a patch. The initial position of each drifter was determined with differential GPS, and a CTD cast was taken coincident with each release. These data provided information on the location of the drifters relative to the coastal plume. Specifically, drifters deployed in salinities of $\sim 30.5$ psu were considered to be in the coastal plume, and those in salinities $\geq 31.0 \mathrm{psu}$, in ambient shelf water. Because plankton samples were analyzed on the day of collection, we immediately were able to identify those drifters that had been deployed in patches ( $>75$ larvae $\mathrm{m}^{-3}$ ). We assigned 75 larvae $\mathrm{m}^{-3}$ to describe a patch because this concentration is substantially higher than background (inter-patch) densities of larvae in our study area (Dittel \& Epifanio 1982). The area around each of these drifters was sampled the following day to ensure that the drifter was still in a patch. Drifters were

Table 1. Callinectes sapidus patch sampling, 1999. Details of drifter deployments and larval patch surveys in the coastal waters adjacent to Delaware Bay, USA. Fewer drifters were deployed each day as the season progressed because drifters were lost and destroyed. No drifters were placed in patches on 15-16 July and 24 August. These drifters were recovered within 24 h of deployment

\begin{tabular}{|c|c|c|c|c|c|c|c|c|}
\hline $\begin{array}{l}\text { Deploy- } \\
\text { ment } \\
\text { date }\end{array}$ & $\begin{array}{l}\text { Transect } \\
\text { length } \\
\text { (m) }\end{array}$ & $\begin{array}{c}\text { No. of } \\
\text { drifters } \\
\text { deployed } \\
\text { in patches/ } \\
\text { total deployed }\end{array}$ & $\begin{array}{l}\text { Drifter } \\
\text { number } \\
(\mathrm{DN})\end{array}$ & $\begin{array}{c}\text { Temperature } \\
\left({ }^{\circ} \mathrm{C}\right), \text { salinity } \\
\text { (psu) at } \\
\text { drifter } \\
\text { release }\end{array}$ & $\begin{array}{l}\text { Dates } \\
\text { drifter } \\
\text { in the } \\
\text { water }\end{array}$ & $\begin{array}{l}\text { No. of } \\
\text { times } \\
\text { patch } \\
\text { sampled }\end{array}$ & $\begin{array}{l}\text { Last day } \\
\text { location } \\
\text { within } \\
\text { patch } \\
\text { verified }\end{array}$ & $\begin{array}{c}\text { Reason sampling } \\
\text { ended }\end{array}$ \\
\hline $5 \mathrm{Jul}$ & 7200 & $1 / 4$ & 1 & $20.3,30.40$ & 5-9 Jul & 4 & $8 \mathrm{Jul}$ & Caught on pot buoy \\
\hline $15 \mathrm{Jul}$ & 7200 & $0 / 4$ & - & - & - & - & - & - \\
\hline $16 \mathrm{Jul}$ & 7200 & $0 / 4$ & - & - & - & - & - & - \\
\hline $27 \mathrm{Jul}$ & 5400 & $2 / 2$ & 2 & $21.3,30.90$ & 27 Jul-3 Aug & 6 & 1 Aug & Beached \\
\hline $27 \mathrm{Jul}$ & 5400 & $2 / 2$ & 3 & $21.7,30.85$ & 27 Jul-7 Aug & 7 & 7 Aug & $\begin{array}{l}\text { Recovered-at limit of } \\
\text { sampling area }\end{array}$ \\
\hline $21 \mathrm{Jul}$ & 7200 & $1 / 4$ & 4 & $20.2,31.25$ & 21-23 Jul & 2 & $23 \mathrm{Jul}$ & $\begin{array}{l}\text { Drogue drifted out of } \\
\text { patch }\end{array}$ \\
\hline $12 \mathrm{Aug}$ & 3600 & $2 / 2$ & 5 & $23.2,31.55$ & 12-13 Aug & 2 & $13 \mathrm{Aug}$ & $\begin{array}{l}\text { Recovered-impending } \\
\text { inclement weather }\end{array}$ \\
\hline $12 \mathrm{Aug}$ & 3600 & $2 / 2$ & 6 & $23.3,31.50$ & 12-17 Aug & 1 & $12 \mathrm{Aug}$ & $\begin{array}{l}\text { Recovered-no } \\
\text { sampling-limit } \\
\text { of study region }\end{array}$ \\
\hline 17 Aug & 3600 & $2 / 2$ & 7 & $22.9,31.55$ & 17-21 Aug & 2 & $18 \mathrm{Aug}$ & Destroyed by vessel \\
\hline 17 Aug & 3600 & $2 / 2$ & 8 & $22.6,31.40$ & 17-21 Aug & 2 & $18 \mathrm{Aug}$ & Drogue shredded \\
\hline $24 \mathrm{Aug}$ & 3600 & $0 / 1$ & - & - & - & - & - & - \\
\hline
\end{tabular}


located via a combination of fixes from the ARGOS satellite system and the use of an automated radiodirection finder (Natunewicz \& Epifanio 2001). Resampling of the patch consisted of continuous, $300 \mathrm{~m}$ surface plankton tows along 2 orthogonal $1800 \mathrm{~m}$ transects centered at the drifter. This procedure was repeated daily, weather permitting, until the drifter had slipped from the patch or was disturbed in some way (ship collisions, entanglement in fishing gear, etc.). Overall, 8 patches were tracked for periods ranging from 1 to $11 \mathrm{~d}$ (Table 1). At the end of the study, the satellite-derived trajectories of the drifters were plotted and analyzed in conjunction with hourly wind and Delaware River discharge data.

Mathematical model. Observed trajectories were compared with the predictions of a 2-dimensional advection-diffusion model previously developed to analyze the transport of blue crab larvae spawned in an estuary such as Delaware Bay (Garvine et al. 1997). Because most Callinectes sapidus larvae remain in the

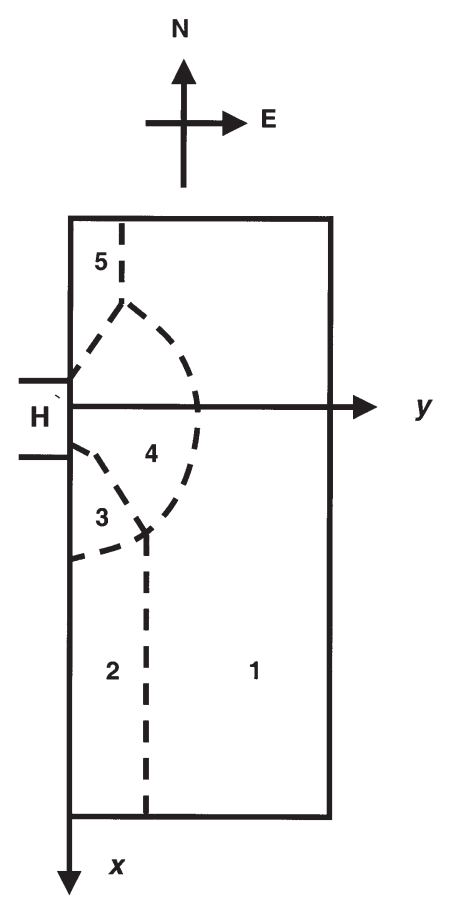

Fig. 2. Mathematical model domain (Garvine et al. 1997). Continental shelf adjacent to Delaware Bay. The $x$-axis indicates along-shelf (approx. north-south) dimension, the $y$-axis the across-shelf (approx. east-west) direction. H represents the mouth of Delaware Bay. Region 1 is forced solely by winds. Region 2, the Delaware Coastal Current, is influenced by a combination of wind and buoyancy forcing. In this region, the across-shelf current tapers to zero at the coast. Region 3, the source region of the Delaware Coastal Current, is affected by winds and buoyancy-forcing. Circulation in region 4 is driven by a mean landward current that balances the outflow of the coastal plume. Region 5 is forced only by wind, and cross-shelf circulation tapers to zero at the coast plankton for weeks or longer, tidal circulation has little effect on their long-term movement. Larval advection in the model is therefore dominated by subtidal currents driven by a combination of surface wind stress over the continental shelf and buoyant discharge from the bay. The tides, however, do provide the effective turbulent energy for diffusion (Garvine et al. 1997).

Garvine et al. (1997) prescribed the Eulerian currents $u$ and $v$ within the model domain based on a realistic synthesis of the major characteristics of subtidal circulation in this coupled estuary-shelf system (Bumpus 1973, Beardsley et al. 1976, Noble et al. 1983, Garvine 1991, Münchow \& Garvine 1993, Wong \& Münchow 1995). The model is driven by along-shelf wind that oscillates at several-day time scales and by river discharge that varies over longer time scales. Given these 2 forcing agents, the Eulerian currents are prescribed based on a set of empirical transfer coefficients that relate the response of the current to wind and buoyancy forcing.

Recent studies in Delaware Bay suggest that the effect of estuarine buoyant discharge on shelf circulation is mostly limited to the inner shelf south of the bay mouth and may vary at monthly time scales (Garvine 1991, Münchow \& Garvine 1993). At shorter time scales of several days to a week, the subtidal current fluctuations on the shelf are dominated by wind forcing (Beardsley et al. 1976, Boicourt \& Hacker 1976, Noble et al. 1983).

The field studies cited show that the mean surface current and the surface current responses to buoyancy and wind forcing vary in space on the shelf off Delaware Bay. To include these spatial variations in the model, Garvine et al. (1997) subdivided the model into 5 regions, each of which was governed by a different flow regime (Fig. 2). Specifically, flow in Regions 1 and 5 was forced solely by along-shelf winds. Region 2 represented the coastal plume emanating from the estuary (i.e., the Delaware Coastal Current), wherein flow was driven by a combination of wind and buoyancy forcing. Region 3 was the source region of the plume, and again flow was influenced by wind and buoyancy forcing. Flow in Region 4 consisted of a mean landward current that balanced the outflow of the plume.

We conducted 1 model run for each drifter deployment. For each simulation we used hourly wind data and daily discharge data for the time period of interest. Each run consisted of releasing a virtual patch within the plume region near the mouth of Delaware Bay. Each modeled patch was 'released' at approximately the same position on the shelf as the corresponding observed patch. Modeled trajectories of the virtual patches were then plotted and compared to trajectories of actual patches during the same time period. 

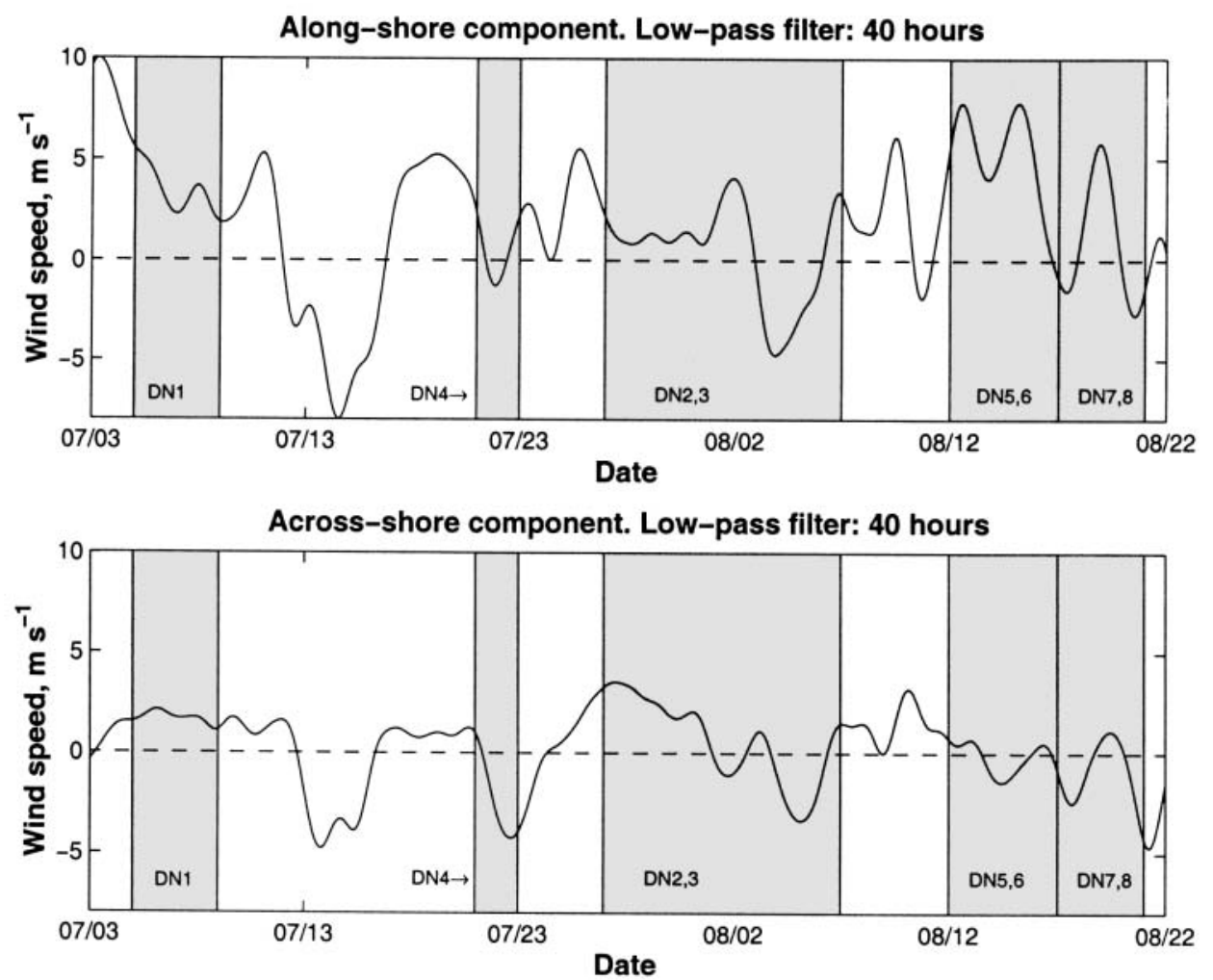

Fig. 3. Along-shore and across-shore components of wind velocity, July-August 1999. Delaware Light Buoy \#44009. 40 h lowpass filter. Along-shore: positive values indicate northward winds, negative values southward winds. Across-shore: positive values are directed offshore. Shaded areas designate periods during which drifters tracked patches

\section{RESULTS}

\section{Winds and river discharge}

The study period encompassed the dates 5 July to 21 August, 1999. Weather patterns were typical of the summer season and included extended periods of light to moderate northward winds $\left(<5 \mathrm{~m} \mathrm{~s}^{-1}\right)$ punctuated by episodes of moderate southward winds (Fig. 3). The region experienced drought conditions during late summer. River discharge over the study period was $\sim 80 \mathrm{~m}^{3} \mathrm{~s}^{-1}$ (Fig. 4), with the exception of a single large event in mid-August. This event did not affect our study, however, because it takes the Delaware Coastal Current about 2 wk to respond to changes in river discharge at Trenton (Garvine 1991).

\section{Initial characteristics of tagged patches}

Drifters were released either in the coastal plume or in shelf water adjacent to the plume. The plume region was characterized by water temperatures that were generally cooler and less saline $\left(\leq 22.5^{\circ} \mathrm{C},<31.0 \mathrm{psu}\right)$ than the surrounding coastal waters $\left(>22.5^{\circ} \mathrm{C}\right.$,

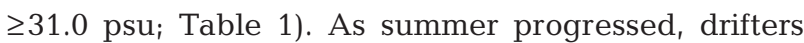
were placed more often in adjacent coastal waters. Because drifters were released along the same transect throughout the study period, the predominance of deployments within higher-salinity water indicates that the size and effect of the coastal plume diminished throughout the summer.

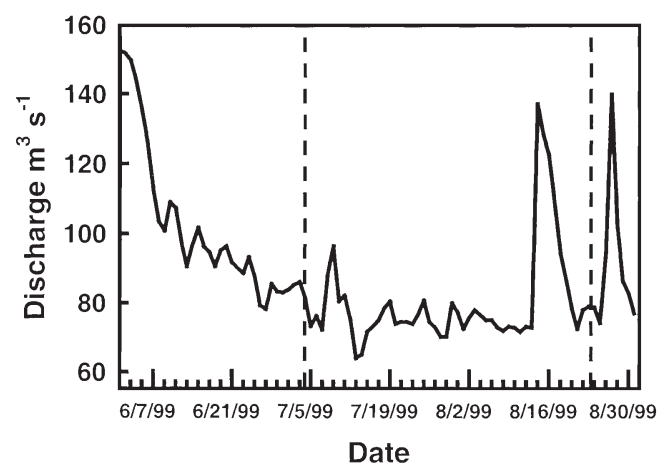

Fig. 4. Delaware River discharge, 1999. Daily discharge measured at the USGS station in Trenton, NJ, during the summer of 1999. The study period (5 July to 22 August) is indicated by dashed lines. Discharge was generally low $\left(\sim 80 \mathrm{~m}^{3} \mathrm{~s}^{-1}\right)$ throughout the course of the study 


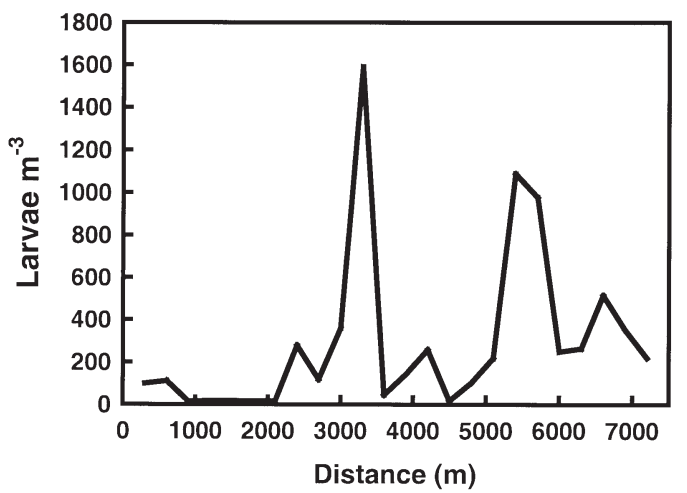

Fig. 5. Callinectes sapidus. 21 July 1999. Larval concentrations along a $7.2 \mathrm{~km}$ transect near the mouth of Delaware Bay. Sampling consisted of twenty-four $300 \mathrm{~m}$ continuous plankton tows. Two distinct patches occur on this transect ( 2100-4200 $\mathrm{m}$ and $4500-7200 \mathrm{~m})$

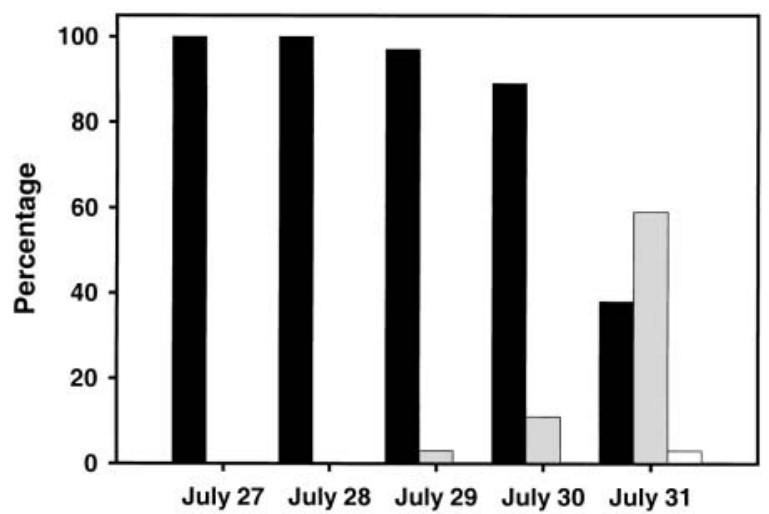

Fig. 6. Callinectes sapidus. Change through time of the zoeal stage composition of the patch marked with DN3. The percentage of total larvae within the patch that are Z-I are indi-

cated with black, Z-II with gray, and Z-III with white

Our initial sampling transect was located within a few $\mathrm{km}$ of blue crab hatching grounds in the mouth of Delaware Bay (Epifanio 1995). As in previous work (Natunewicz \& Epifanio 2001), initial larval patch dimensions were on the scale of kilometers in the along-shelf direction (Fig. 5). Initial concentration within the patches ranged from approximately $10^{2}$ to $10^{3}$ larvae $\mathrm{m}^{-3}$. When tagged patches were re-sampled on subsequent days, larval concentrations along the west-east transect in the tagged patches were always similar to those along the corresponding north-south transect.

Newly tagged patches were always dominated by 1st-stage zoea larvae (Z-I), and patches continued to be dominated by Z-I for 2 to $3 \mathrm{~d}$ thereafter. However, patches that were followed for longer periods of time eventually had increased proportions of advanced stages (Fig. 6). The most parsimonious explanation for this change is sequential molting of Z-I through the subsequent zoeal stages.

\section{Trajectories}

Trajectories of 8 larval patches were plotted from the series of drifter coordinates obtained from the ARGOS satellite system. Movement of patches depended on their location relative to the coastal plume and on wind speed and direction. To simplify discussion of our results, we assigned patch trajectories to 1 of 3 groups: patches released in the coastal plume (Fig. 7); patches released in the ambient continental shelf waters and subjected to light $\left(<5 \mathrm{~m} \mathrm{~s}^{-1}\right)$ wind-forcing (Fig. 8); and patches tagged in shelf waters and influenced by strong $\left(>5 \mathrm{~m} \mathrm{~s}^{-1}\right)$ wind forcing (Fig. 9).

Patches in the coastal plume initially traveled southward, away from the parent estuary. For example, the patch tagged on 5 July with Drifter Number 1 (DN1) traveled southward in the plume until 8 July. Winds throughout this period were generally light and northward $\left(<5 \mathrm{~m} \mathrm{~s}^{-1}\right.$; Fig. 3). After 8 July, the drifter became caught on a fish-trap buoy. Plankton sampling around the entangled drifter on 9 July indicated that drifter was no longer in the patch (Fig. 7A-1). The lack of larvae around the entangled drifter lent credence to our assumption that functional drogues accurately tagged patches, yet entangled or torn drifters did not.

Two other drifters (DN2, DN3) were deployed in coastal-plume patches on 27 July. These patches were tracked for 6 and $11 \mathrm{~d}$, respectively. Winds during this period were initially northward and light (Fig. 3). On 2 August the wind remained northward, but increased to over $5 \mathrm{~m} \mathrm{~s}^{-1}$. The wind shifted again on 3 August, blowing moderately ( 3 to $9 \mathrm{~m} \mathrm{~s}^{-1}$ ) in a southward direction.

Patch trajectories are very sensitive to their initial positions. Therefore patches that co-occurred in time, yet were tagged at different locations across the continental shelf, followed different paths. This was evident in the trajectories of DN2 and DN3. DN2 initially moved south and offshore in the coastal plume (Fig. 7B-1). The drifter then moved inshore near Fenwick Shoal, a shallow area near Ocean City, Maryland (Fig. 1). As the magnitude of the northward (upwelling-favorable) winds increased, DN2 moved offshore. Moderate southward (downwelling-favorable) winds then returned the drifter onshore, circulating the patch around Fenwick Shoal before beaching the drifter near Ocean City late on 3 August.

The patch marked by DN3 initially followed a similar trajectory, moving southward in the plume to an area near Fenwick Shoal (Fig. 7C-1). The drifter then traveled offshore with upwelling-favorable winds. As with DN2, subsequent motion of DN3 was strongly related 

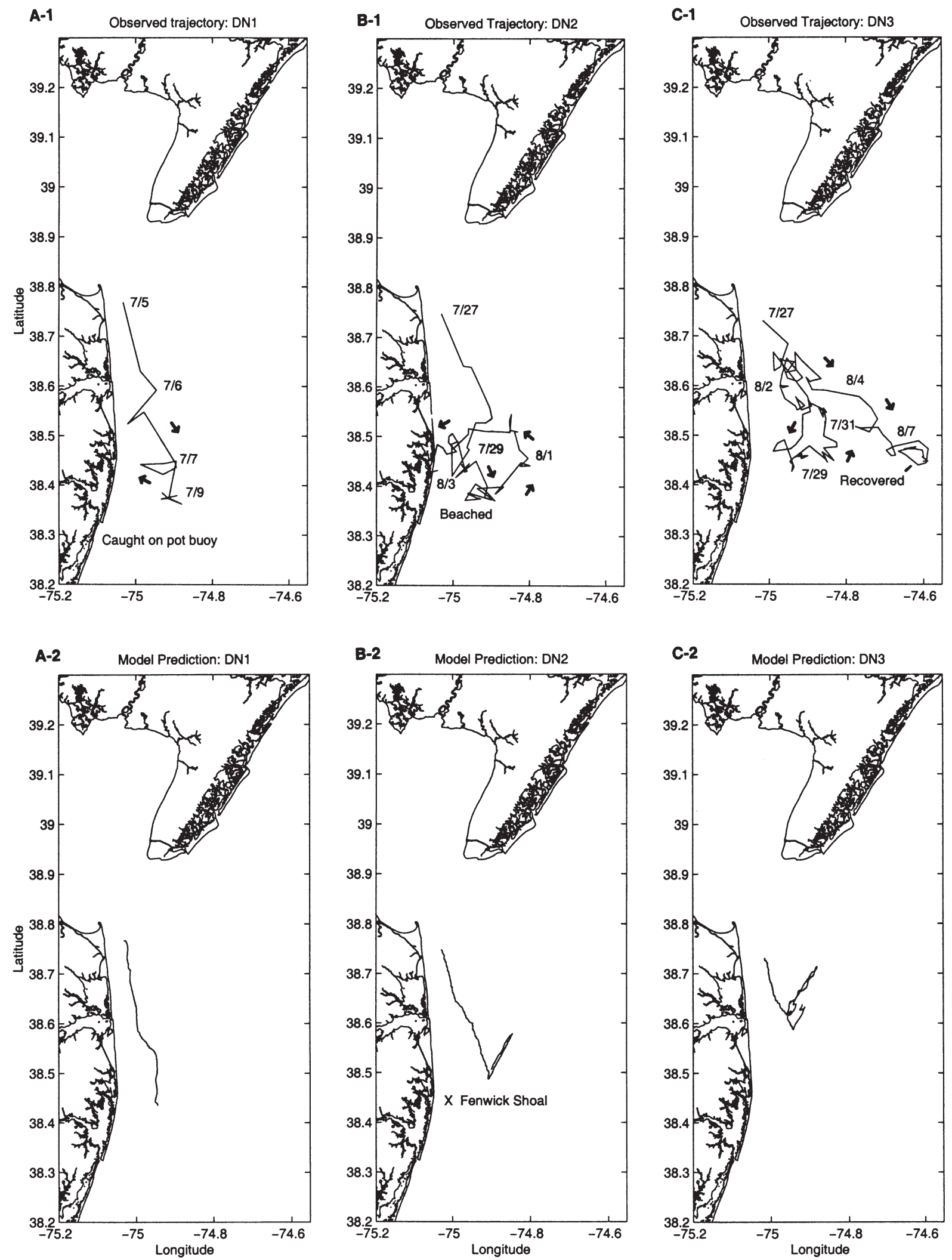

Fig. 7. Callinectes sapidus. Coastal plume drifter releases. Observed (A1, B1, C1) and modeled (A2, B2, C2) trajectories of patches of larvae released in the coastal plume adjacent to Delaware Bay. Panels A1, 2 = DN1, 5-9 July. Panels B1, 2 = DN2, 27 July-3 August. Panels C1, 2 = DN3, 27 July-7 August. DN2 and DN3 were released $1800 \mathrm{~m}$ apart on the same day. They marked 2 distinct patches 

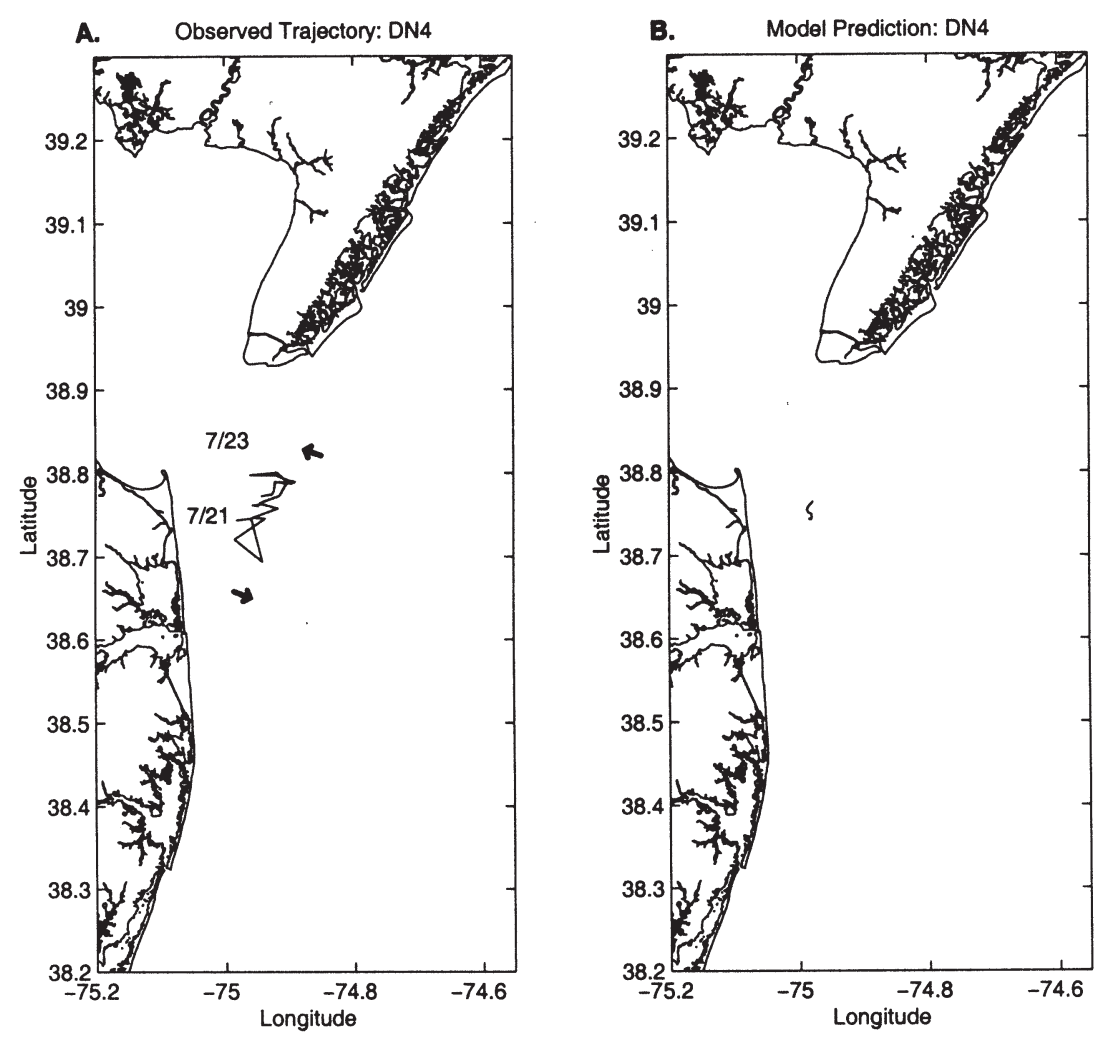

Fig. 8. Callinectes sapidus. Continental shelf drifter releases. Weak wind-forcing. DN4; 21-23 July. Observed (A) and modeled (B) trajectories of a patch of larvae released on the continental shelf adjacent to Delaware Bay. Winds over the $2 \mathrm{~d}$ tracking period were generally light $\left(<5.0 \mathrm{~m} \mathrm{~s}^{-1}\right)$ and variable

to the occurrence of upwelling- and downwellingfavorable winds and involved several onshore/offshore excursions. The drifter was sampled and recovered on 7 August, when its distance from shore had nearly exceeded the cruising range of our research vessel.

The initial trajectories of patches tagged in adjacent shelf waters outside of the coastal plume were more variable and were highly dependent on wind velocity (Figs 8 \& 9). DN4 was released in a patch on 21 July and remained with the patch until 23 July (Fig. 8A). The patch remained near the mouth of Delaware Bay, with light northward winds pushing the patch northward on 21 July, and southward winds transporting the patch back toward the bay on 22 July. Small-amplitude, high-frequency variations in the trajectory were probably related to tidal flow.

Two additional drifters (DN5 and DN6) were deployed in adjacent-shelf patches on 12 August. Winds during 12-13 August were generally light and northward (Fig. 3). In these conditions, the patch marked with DN5 traveled offshore and slightly southward. Although DN5 still marked a patch on 13 August, the drifter was recovered due to predictions of storm conditions in the area.

Inclement weather precluded the recovery of DN6 until 17 August. During this period, the drifter traveled north and offshore in response to strong upwellingfavorable (northward) winds (Fig. 9A-1). Because the drifter was not re-sampled after 13 August, it is not known how long the drifter remained in the patch.

The final deployments (DN7, DN8) occurred on 17 August. CTD data indicated that these drifters were released in shelf waters. The patches were re-sampled only 1 time (18 August), due to subsequent inclement weather. On 18 August, strong (>5.0 $\left.\mathrm{m} \mathrm{s}^{-1}\right)$ northward winds drove both patches eastward across the continental shelf (Figs 3 \& 9B-1). Moderate southward winds over 20-21 August returned the patches inshore to the mouth of Delaware Bay. DN7 was never recovered and was presumably destroyed in a ship collision. DN8 was damaged by entanglement with fishing gear before its eventual recovery on 21 August. Thus, any interpretation of trajectories after 18 August must be regarded cautiously.

\section{Comparison with model simulations}

The advection-diffusion model reproduced the transport of patches located in a coastal plume with reasonable fidelity (Fig. 7). Predicted trajectories of 

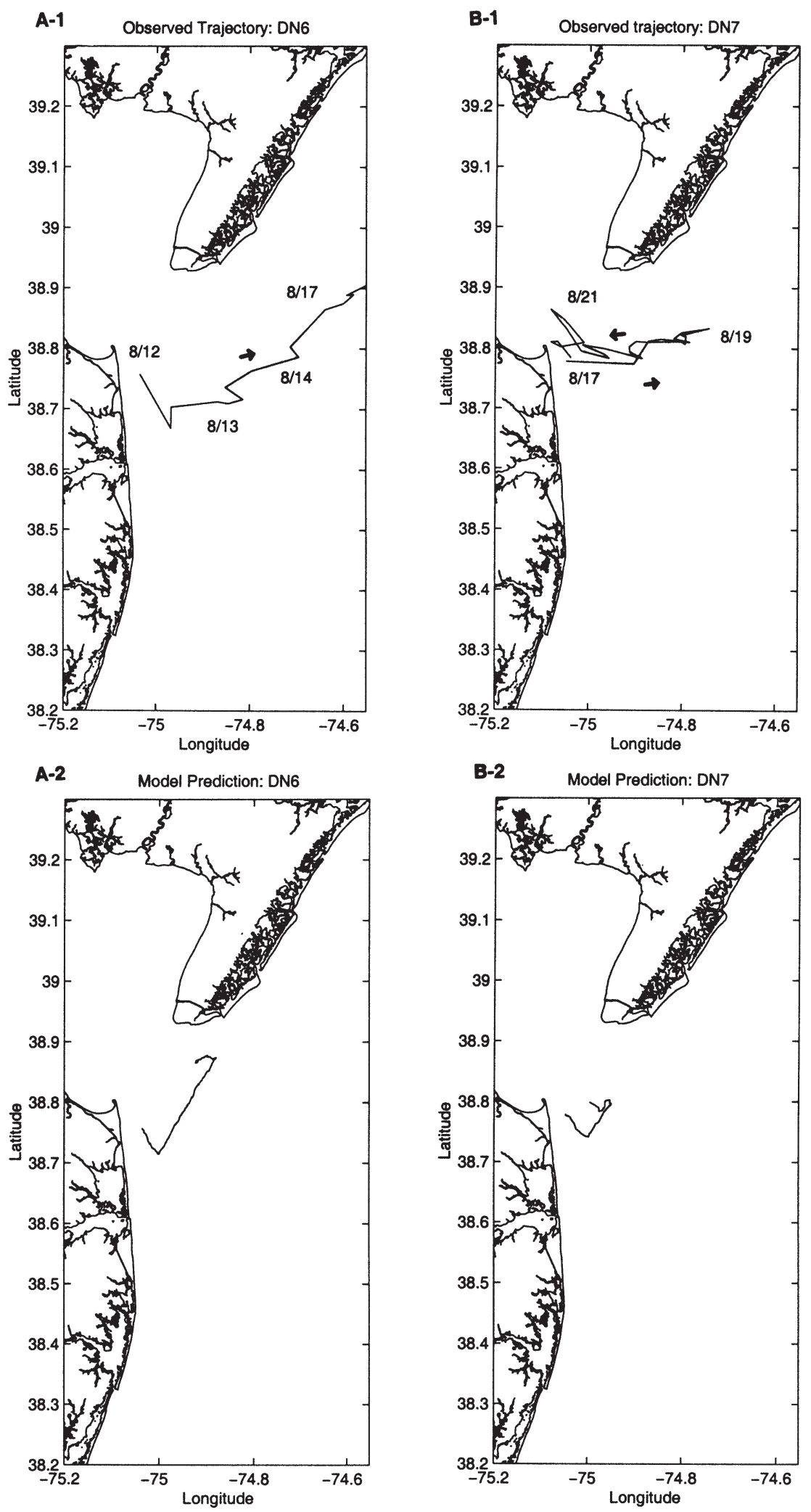

Fig. 9. Callinectes sapidus. Continental shelf drifter releases. Strong wind-forcing. Observed (A1, B1) and modeled (A2, B2) trajectories of larval patches released on the continental shelf adjacent to Delaware Bay. Panels A1, 2 = DN6, 12-17 August. Strong $\left(>5.0 \mathrm{~m} \mathrm{~s}^{-1}\right)$ upwelling-favorable winds occurred over this period, driving the patch marked with DN6 northward and offshore. Panels B1, 2 = DN7, 17-22 August. Strong upwelling-favorable winds pushed the larval patch marked with DN7 offshore. Moderate $\left(\sim 5.0 \mathrm{~m} \mathrm{~s}^{-1}\right)$ downwelling-favorable winds then returned the patch shoreward and into the estuary 
plume patches all showed initial transport to the south with subsequent movement dependent on wind forcing. However, the model failed to reproduce fine-scale motion such as the cyclonic movement of DN2 and DN3 around Fenwick Shoal (Fig. 7B,C).

The model was generally more successful in predicting trajectories of the adjacent-shelf patches. Trajectories of patches tagged by DN4, DN6, and DN7 were predicted with good accuracy for periods up to $6 \mathrm{~d}$ (Figs 8 \& 9). Although the model often underestimated the magnitude of across-shelf transport of the drifters, it nonetheless produced a useful approximation of the observed trajectories (Figs $8 \& 9$ ).

\section{DISCUSSION}

Results of our investigation showed that initial transport of blue crab larvae from Delaware Bay to the continental shelf is driven by buoyancy forcing in the Delaware Bay plume region and by wind forcing over the continental shelf. The influence of the plume was strongest in the early part of the blue crab spawning season, as patches tagged in July were transported farther south along the continental shelf than those released later in the summer. Patches tagged in August were all located in shelf water adjacent to the coastal plume, indicating that patches had been transported out of the plume very soon after hatching. This is most likely an effect of wind-driven upwelling circulation.

The high number of Z-I found at the deployment sites indicated that patches were initially tagged within 1 to $5 \mathrm{~d}$ of hatching (Natunewicz \& Epifanio 2000). Patches tracked for periods longer than $4 \mathrm{~d}$ had high concentrations of Z-II in addition to Z-I (Fig. 6). The patch tracked for a period $>7 \mathrm{~d}$ had relatively high concentrations of Z-III and Z-IV. These stage-composition data match well with laboratory-derived growth rates of Callinectes sapidus larvae (Costlow \& Bookhout 1959, Sulkin 1975, 1978).

Patches tagged in the plume region always showed an initial southward trajectory. This southward transport was evident during conditions of light northward winds $\left(<5 \mathrm{~m} \mathrm{~s}^{-1}\right)$. The strength of the buoyancy-driven flow was therefore sufficient to overcome effects of light wind forcing. Stronger northward winds $(>5 \mathrm{~m}$ $\mathrm{s}^{-1}$ ) tended to set up an Ekman response and push the drifters offshore and out of the coastal plume (Lentz 1994). Downwelling-favorable (southward) winds returned the larvae inshore. This across-shelf motion was especially evident during the 27 July deployment, when downwelling circulation resulted in the beaching of DN2 by the 7th day of tracking (Fig. 7B).

The coastal plume was not as well-defined in late July and August as it was in early July. Drifters released after 27 July were placed in continental shelf waters rather than in the low-salinity regions of the estuarine plume. Weak discharge from the Delaware River minimized the initial southward transport of patches, allowing the patches to be mixed out of the coastal plume more readily. Thus, larvae released later in the summer were retained closer to the mouth of the Delaware Bay than those released earlier in the summer.

The mathematical model predicted the qualitative features of the drifter trajectories quite well. Specifically, the model reproduced 2 transport regimes based on the position of larval release relative to the coastal plume: southward transport for larvae hatched within the coastal plume (Fig. 7), and retention nearer to the bay mouth for larvae released in continental shelf waters (Figs $8 \& 9$ ). Release within the coastal plume did not, however, guarantee strictly southward movement, as the proximity of larval release to the edge of the coastal plume profoundly affected transport. For example, both observed and modeled patches that were initially located in the shoreward region of the coastal plume remained near the coast throughout the tracking/modeling period (Fig. 7A). In contrast, patches located closer to the seaward edge of the coastal plume initially moved southward, but were then driven offshore and into the mean northward mid-shelf current by northward winds (Fig. 7B,C). The sensitivity of larval transport to hatching/release location within the coastal plume was therefore shown by both the observed drifter trajectories and those predicted by the mathematical model.

Larvae released in the ambient shelf were subject to the different transport regime. These larvae did not show initial southward transport, but rather remained at roughly the same latitude as the mouth of the bay. Observed and modeled patches that were initially located in continental shelf waters outside the plume were especially susceptible to wind forcing, traveling offshore and onshore with northward and southward winds, respectively (Fig. 9). Larvae hatching in shelf waters outside the plume would therefore have a higher probability of returning to the parent estuary, making release and subsequent movement in shelf waters the more favorable of the 2 transport regimes.

Although the mathematical model predicted the general patterns of larval transport, it did not capture some of the small-scale circulation features. First, the mathematical model did not predict the fine-scale tidal flow evident in the observed drifter trajectories (e.g., Fig. 7A). This occurred because the mathematical model treats only subtidal frequency forcing agents and could therefore not predict the tidally induced movement of the drifters. Additionally, the model did not predict the cyclonic movement of DN2 and DN3 
around Fenwick Shoal (Fig. 7B,C), because the model lacks bathymetry. Finally, the model underestimated the magnitude of cross-shelf transport (Figs 8 \& 9). Despite the fact the mathematical model did not reproduce some of the small-scale features of larval transport, it nevertheless described well the general trajectories of patches of Callinectes sapidus larvae subject to 2 different transport regimes. This suggested that the 2 main factors that influence larval transport at daily to weekly time scales, namely winds and buoyancy, are described adequately by the model.

Our investigation is one of very few that have tracked patches of fish or invertebrate larvae in the coastal environment. The study is unique in the use of remote sensing platforms (earth-orbiting satellites) to make high-frequency observations over periods as long as $11 \mathrm{~d}$. The work differs from earlier efforts (e.g., Fortier \& Leggett 1985, Roman \& Boicourt 1999, Voss et al. 1999) in the initial characterization of the tagged patches, i.e., spatial scale of the patch, spatial distribution of larval concentrations within the patch, and magnitude of larval concentrations outside the patch. This initial characterization assured that drifters were actually deployed within a patch, and subsequent sampling of the area around the drifters allowed determination that a drifter remained within a patch through time.

Overall, the results of our study support conceptual and mathematical models of blue crab transport in the Middle Atlantic region (Epifanio 1995, Garvine et al. 1997). Larvae are transported from Delaware Bay to the adjacent coastal ocean in discrete patches, which maintain their integrity on a scale of days to weeks. Initial trajectories of the patches depend on the interaction between buoyancy-driven flow emanating from the bay and wind-driven flow on the shelf. Buoyancydriven flow is typically stronger in the early part of the blue crab spawning season (June/July), and patches produced during this period are likely to be transported greater distances to the south and away from the parent estuary. Patches produced later in the spawning season (August/September) are more likely to be influenced by upwelling circulation with consequent mixing out of the coastal plume and consequent retention near the parent estuary. The effects of upwelling circulation on retention are likely to be most pronounced during drought years, when buoyancy driven flow is minimal. Present models of blue crab transport in the Middle Atlantic Bight indicate that recruitment of blue crabs to juvenile nurseries is dependent on (1) the availability of patches of settlement-competent larvae near the mouth of the estuary and (2) the co-occurrence of southward wind events to transport the larvae into the estuary. The results of our investigation indicate that the availability of patches may be maximal during drought years, when buoyancy-driven flow is at a relative climatological minimum.

Acknowledgements. This study was funded by Delaware Sea Grant (RF-10) and the National Science Foundation (GER9453990). We would like to thank 3 anonymous reviewers for their helpful comments on earlier versions of this manuscript. A. Sundberg provided technical support for both the electronics equipment and the RV 'Captain White'. Field assistance was provided by Captain M. B. Jones, C. Petrone, G. Perovich, S. Park, C. Kopin, A. LePard, C. Tallamy, R. Weaver, L. Popels, C. Milbury, S. Ni Chadhain, and S. Sue. Computer and technological support was provided by M. Medvedeva, R. Zagar, C. Janzen and M. Whitney.

\section{LITERATURE CITED}

Brown J, Hill AE, Fernand L, Horsburgh K (1999) Observations of a seasonal jet-like circulation at the central North Sea cold pool margin. Estuar Coast Shelf Sci 48: 343-55

Beardsley RC, Boicourt WC, Hansen DV (1976) Physical oceanography of the Middle Atlantic Bight. Am Soc Limnol Oceanogr Spec Symp 2:20-34

Boicourt WC, Hacker PW (1976) Circulation on the Atlantic continental shelf of the United States, Cape May to Cape Hatteras. Mém Soc R Liége 6 Sér 10:187-200

Bumpus DF (1973) A description of the circulation on the continental shelf of the east coast of the United States. Prog Oceanogr 6:111-157

Costlow JD, Bookhout CG (1959) The larval development of Callinectes sapidus Rathbun reared in the laboratory. Biol Bull 16:373-396

Dittel AI, Epifanio CE (1982) Seasonal abundance and vertical distribution of crab larvae in Delaware Bay. Estuaries 5(3):197-202

Epifanio CE (1995) Transport of blue crab (Callinectes sapidus) larvae in the waters off mid-Atlantic states. Bull Mar Sci 57:713-725

Fortier L, Leggett WC (1985) A drift study of larval fish survival. Mar Ecol Prog Ser 25:245-257

Garvine RW (1991) Subtidal frequency estuary-shelf interaction: observations near Delaware Bay. J Geophys Res 96:7049-7064

Garvine RW, Epifanio CC, Epifanio CE, Wong KC (1997) Transport and recruitment of blue crab larvae: a model with advection and mortality. Estuar Coast Shelf Sci 45: 99-111

Jones MB, Epifanio CE (1995) Settlement of brachyuran megalopae in Delaware Bay: an analysis of time series data. Mar Ecol Prog Ser 125:67-76

Lentz SJ (1994) Current dynamics over the northern California inner shelf. J Phys Oceanogr 24:2461-2478

Münchow A, Garvine RW (1993) Buoyancy and wind forcing of a coastal current. J Mar Res 51:293-322

Natunewicz CC, Epifanio CE (2001) Spatial and temporal scales of patches of crab larvae in coastal waters. Mar Ecol Prog Ser 212:217-222

Noble M, Butman B, Williams E (1983) On the longshelf structure and dynamics of subtidal currents on the eastern United States Continental Shelf. J Phys Oceanogr 13: 2125-2147

Pepin P, Helbig JA (1997) Distribution and drift of Atlantic cod (Gadus morhua) eggs and larvae on the Northeast Newfoundland shelf. Can J Fish Aquat Sci 54:670-685 
Richerson PJ, Powell TM, Leight-Abbott MR, Coil JA (1977) Spatial heterogeneity in closed basins. In: Steele (ed) Spatial patterns in plankton communities. Plenum Press, New York, p 239-276

Roman MR, Boicourt WC (1999) Dispersion and recruitment of crab larvae in the Chesapeake Bay plume: physical and biological controls. Estuaries 22:563-74

Sulkin SD (1975) The significance of diet in the growth and development of larvae of the blue crab, Callinectes sapidus Rathbun, under laboratory conditions. J Exp Mar Biol Ecol 20:119-135

Sulkin SD (1978) Nutritional requirements during larval

Editorial responsibility: Otto Kinne (Editor),

Oldendorf/Luhe, Germany development of the portunid crab, Callinectes sapidus Rathbun. J Exp Mar Biol Ecol 34:29-41

Wong KC, Münchow A (1995) Buoyancy-forced interaction between the estuary and inner shelf: observation. Cont Shelf Res 15:59-88

Voss R, Hinrichsen HH, St. John M (1999) Variations in the drift of larval cod (Gadus morhua L.) in the Baltic Sea: combining field observations and modeling. Fish Oceanogr 8:199-211

Zenitani H, Nakata K, Inagake D (1996) Survival and growth of sardine larvae in the offshore side of the Kuroshio. Fish Oceanogr 5:56-62

Submitted: July 8, 2000; Accepted: August 21, 2001

Proofs received from author(s): October 18, 2001 